\title{
LAND DEGRADATION AND MANAGEMENT WITHIN UPPER RACOVA CATCHMENT
}

\section{Samoilă (Grigoraș) Claudia ${ }^{1}$, Ioniță Ion ${ }^{1}$, Niacșu Lilian ${ }^{1}$, Grigoraș Georgel ${ }^{1}$, Blebea-Apostu Ana Maria ${ }^{2}$}

Key words: soil erosion, landslides, reservoir siltation, conservation practises

\begin{abstract}
Land degradation has been recognized as an important environmental threat in the Moldavian Plateau of eastern Romania. This study was designed to estimate the magnitude of land degradation and to review land management in a small catchment in the Central Moldavian Plateau. Several methods were deployed to estimate soil erosion losses, gully distribution, landslide inventory and reservoir sedimentation rates. Results obtained in the study area of 7,766 ha, of which $31 \%$ is arable and $32 \%$ native forest, show that the mean value of soil losses by water erosion on agricultural land is $19.0 \mathrm{t} \mathrm{ha}^{-1} \mathrm{y}^{-1}$. By adding the woodland contribution, this value significantly decreases to $12.8 \mathrm{t} \mathrm{ha}^{-1} \mathrm{y}^{-1}$. Then, a large proportion of land $(58 \%)$ is covered by landslides. Most of them are shallow and dormant (stable), and the active ones form only $\sim 2 \%$ of the total landslide area. Siltation rates determined using ${ }^{137} \mathrm{Cs}$ reflect the impact of land management on deposition patterns in reservoirs. Proper conservation measures were applied over a 20-year time-span from 1970-1990. Since 1991 the contour farming system collapsed and returned to the traditional 'up-and-down slope' farming system on very small plots.
\end{abstract}

\section{Introduction}

Land degradation by soil erosion, gully erosion and mass movements is an important environmental threat in the Moldavian Plateau of eastern Romania, including the Upper Racova Catchment. Since multiple soil and land functions have been severely affected, the implementation of effective soil conservation practises is imperative.

Previous studies focused on larger areas within the Moldavian Plateau and provided insufficient information about land degradation and land improvements at the smaller catchment scale.

\footnotetext{
1 "Alexandru Ioan Cuza" University of Iasi, Department of Geography, Carol I Blvd. 20 A, 700505 Iasi, Romania, e-mails: samoilaclaudia@yahoo.com \& ion.ionita72@yahoo.com.

2 "Horia Hulubei" National Institute for Physics and Nuclear Engineering, Reactorului Str. 30, P.O. BOX MG-6, Bucharest - Magurele, Romania, e-mail: anapostu@ifin.nipne.ro.
} 
Many publications discuss environmental characteristics (e.g. Bacauanu et al., 1980; Ungureanu, 1993), whereas others focused on specific issues. Based on various sources, Motoc (1983) estimated total erosion on agricultural lands in Romania and suggested rates were especially high on the Barlad Plateau, with an average value of 20-30 tha ha $\mathrm{y}^{-1}$. The large extent of landslides within three catchments (Upper Barlad upstream of Bacesti, Sacovat and Crasna) on the Central Moldavian Plateau was emphasized by Ionita et al. (2014). Reservoir sedimentation is also problematic in the central and southern Moldavian Plateau. Ionita et al. (2000) conducted a preliminary study using the ${ }^{137} \mathrm{Cs}$ technique to estimate sedimentation rates at two sites on the floor of the Puscasi and PungestiGarceana reservoirs.

About three-quarters of degraded agricultural land on the Moldavian Plateau were adequately treated during the short-lived period of proper soil conservation measures. In this context, the aim of the present study is to present both the current state of land degradation and the development of soil conservation measures in the Upper Racova Catchment.

\section{Study area}

Racova Catchment upstream of Pungești, Vaslui County, is located in the south-west section of the Central Moldavian Plateau (Figure 1). It is orientated in a north-west - south-east direction and covers 7,766 ha where live 4,851 inhabitants.

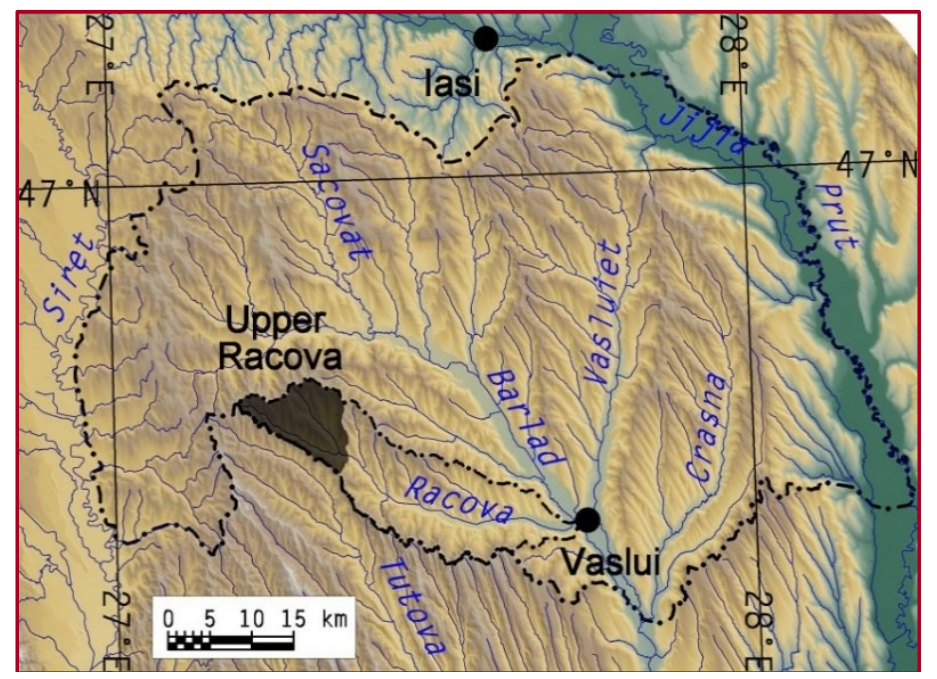

Fig. 1. Location of the study area in Central Moldavian Plateau. 
From the stack of Paleozoic, Mesozoic and Tertiary sedimentary strata, Late Miocene (Upper Sarmatian/Kersonian) layers have outcropped due to erosion. Racova Catchment is sculptured in clayey-sandy and sandy-clayey formations, exclusively deposited in deltaic facies. The thickness of the Kersonian crossbedded strata at Pungești is $\sim 250 \mathrm{~m}$. The Late Miocene sedimentary strata lie in a general homocline structure, with a gentle dip of 7-8 $\mathrm{m} \mathrm{km}^{-1}$ towards the south-east (Jeanrenaud, 1961, 1971; Ionesi, 1994). There are also recent Quaternary formations, including eluvia, diluvia, colluvia, proluvia and alluvia.

The local relief is typically hilly, with extreme altitudes of $460.6 \mathrm{~m}$ a.s.l. on Schitului Hill in the northern watershed and $165.7 \mathrm{~m}$ a.s.l. on the Racova floodplain. About 3,946 ha, representing half of the catchment area, range from 200-300 m a.s.1. (Figure 2).

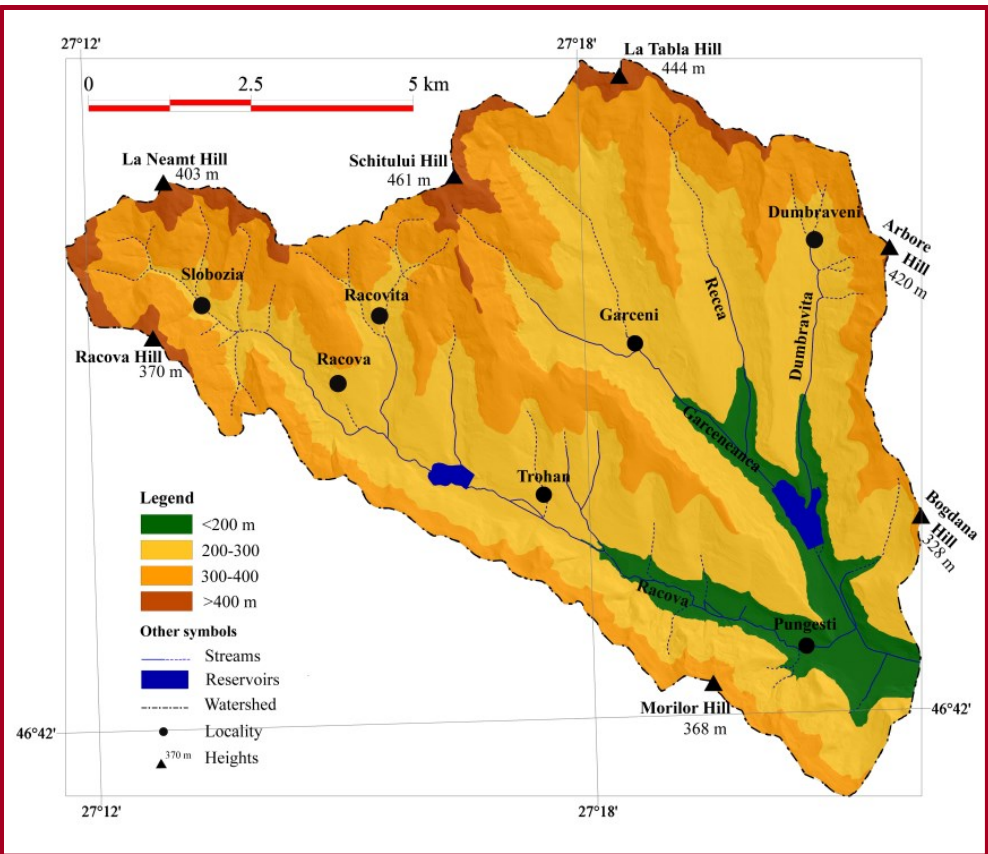

Fig. 2. Hypsometric map in the Upper Racova Catchment.

The overall mean slope of Racova Catchment is estimated to be $19.7 \%$. The highest slope values $>27 \%$ are on the cuesta fronts, in a series of heavily degraded cuesta back-slopes, and in the upper catchment of the tributaries. According to the slope histogram, $85 \%$ of the study area exceeds $5 \%$, which indicates that Upper Racova Catchment has high erosion potential (Figure 3). 
All major relief types typically for the platform areas have been identified, namely: structural, sculptural and accumulation relief. The sculptural (fluviodenudational) topography within the homocline is the prevailing relief type and covers 6,891 ha, representing $88.7 \%$ of the total catchment area. It occurs as two landforms: sculptural hilltops and slopes $(4.1 \%$ and $84.6 \%$, respectively of Upper Racova Catchment). Slopes (valley-sides) usually play the role of cuesta front and/or cuesta back-slope underlining extension of the cuesta relief in the study area (Samoilă Claudia \& Ioniță I., 2017).

Overall, the right side of Upper Racova Catchment is narrow (1,651 ha, 21\% of the total) and mostly consists in a slightly dissected cuesta front and its amplitude does not exceeds $160 \mathrm{~m}$. On the contrary, the left side of Upper Racova Catchment initially represented a broad cuesta back-slope occupying $79 \%$ of the catchment, where Garceneanca valley and its tributaries later incised and developed.

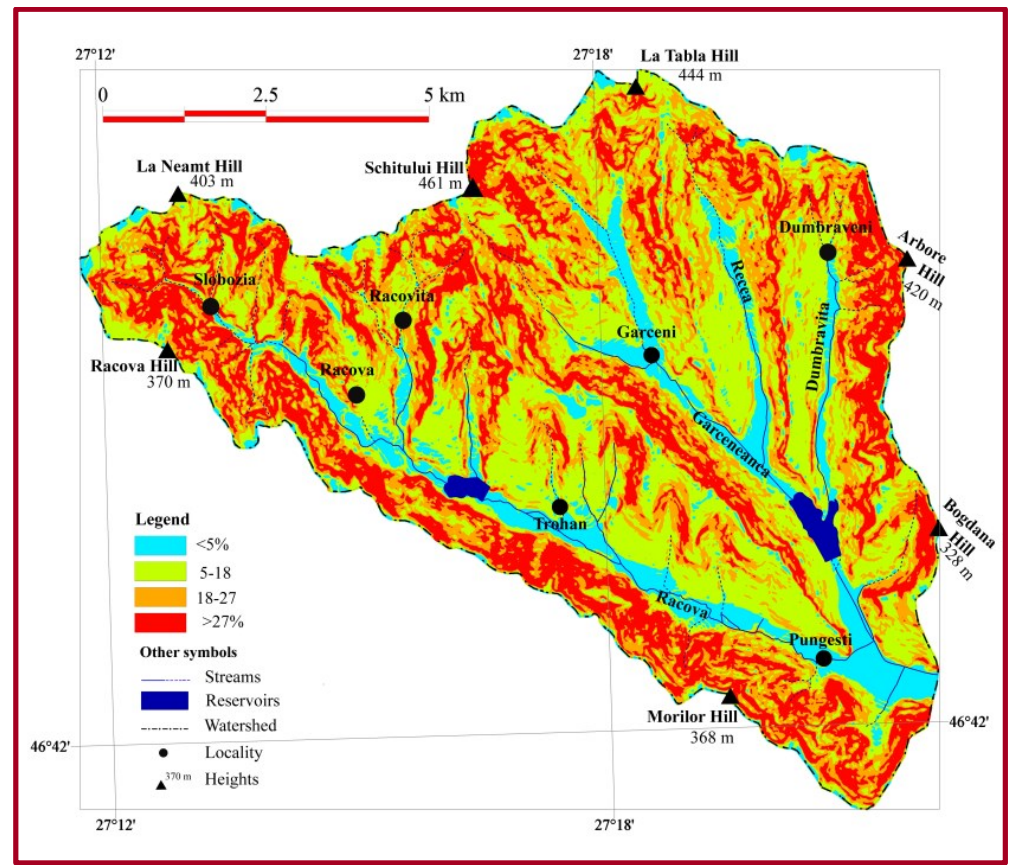

Fig. 3. Slope map (\%) of the Upper Racova Catchment.

Then, the lower eastward dip of $\sim 3 \mathrm{~m} \mathrm{~km}^{-1}$, induced by the more intense tectonic uplifting at the contact with the Carpathian Orogen, resulted in the second order morpho-structural asymmetry. This includes reconsequent valleys, north- 
south oriented (e. g. Racoviţa, Hartag, Recea, Dumbrăviţa) which contain smaller cuestas with west-facing fronts and east-facing back-slopes. Figure 4 illustrates the double morpho-structural asymmetry within Racova Valley, where the first order asymmetry appears in the foreground (Racova village is located on a south facing cuesta back-slope) and the second order asymmetry is visible in the background.

The continental temperate climate is characterized by a mean annual temperature rising from $7.5^{\circ} \mathrm{C}$ on the highest hilltops to $\sim 9.1^{\circ} \mathrm{C}$ at the junction of Racova and Garceneanca valleys. Mean annual precipitation for the period 19862016 varied from $574 \mathrm{~mm}$ at Lipova, Bacau County, at $250 \mathrm{~m}$ a.s.1 to $700 \mathrm{~mm}$ in the area $>400 \mathrm{~m}$ a.s.l. Usually, $65 \%$ of precipitation falls during the warm season (April-September), with the monthly maximum falling in June, with typical totals of 87-98 mm.

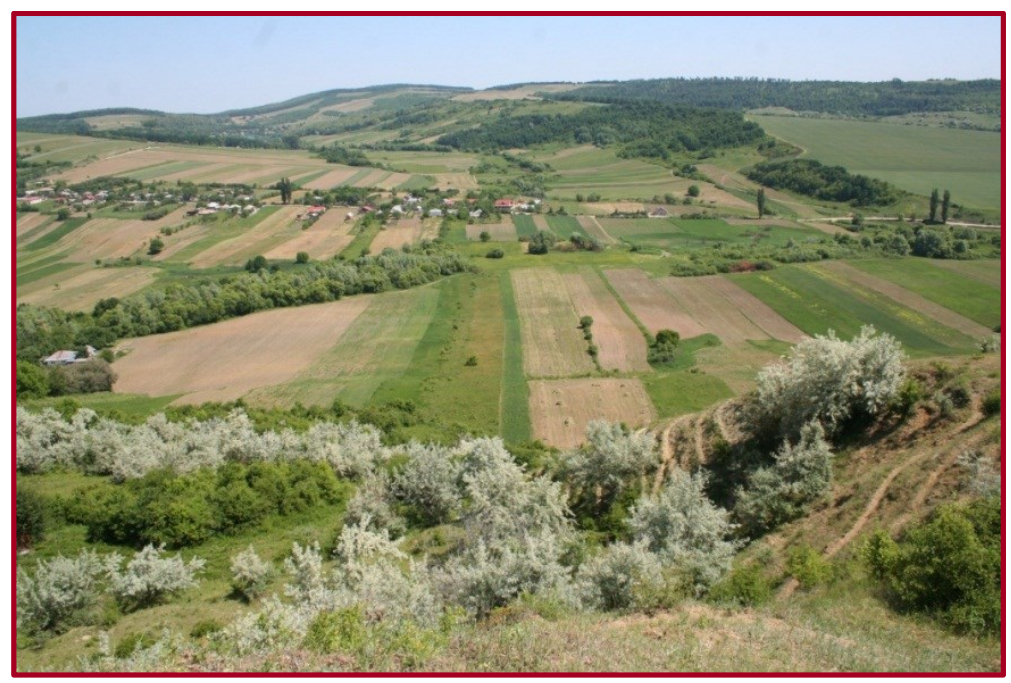

Fig. 4. Double morpho-structural asymmetry within Racova Valley at Racova (02 June 2015)

Racova River is a right tributary of the Barlad Catchment. Mean monthly water discharge of the Upper Racova River does not exceed $0.31 \mathrm{~m}^{3} \mathrm{~s}^{-1}$ and shows significant pulses in connection with the climatic conditions.

Bio-pedo-geographically, the study area is covered with deciduous forest, where there is a gradual transition from common beech (Fagus silvatica) to the prevalent durmast (Quercus petraea). Accordingly, the zonal soils are Luvisols, where Entic Luvisols prevail and alternate with Luvisols. A large proportion of slopes is mantled by less productive soils (Erodosols and Regosols), depending on 
the stage of land degradation processes. Most floodplain soils are Alluviosols and Hydrisols.

Agricultural land covers $62.7 \%(4,871 \mathrm{ha})$ of the catchment area. Some $31.2 \%$ is arable and $30.8 \%$ is pasture. The proportion of non-agricultural land is $37.3 \%$ (2,895 ha), of which native forest covers $31.8 \%$ (2,472 ha). Initially, this area was entirely under forest. Then, it was severely deforested during the $18^{\text {th }}$ and especially the $19^{\text {th }}$ Century, and the forest has remained fairly constant since the late $19^{\text {th }}$ Century.

\section{Methods}

Several methods were deployed to estimate soil erosion losses, gully distribution, landslide inventory and reservoir sedimentation rates. Firstly, a Digital Elevation Model (DEM) was created by digitizing the national 1:5,000 topographic maps using TNT Mips version 6.9 software. The Universal Soil Loss Equation (USLE) developed by Wischmeier \& Smith $(1960,1978)$ with its six factors, as adopted for Romanian conditions (Motoc, 1970; Motoc et al., 1975), was used to estimate long-term average annual soil loss from Upper Racova Catchment.

Information for present-day land use was abstracted from the 2009 aerial orthorectified imagery and the 1:5,000 topographic maps. These sources, together with the 2012 LiDAR images, have been successfully used to draw gully outlines and especially land covered by landslides.

A topographic survey was made using a Leica 407 TCR and GPS South 82VTrimble in spring 2018, when Pungesti Reservoir was temporarily almost emptied. The ${ }^{137} \mathrm{Cs}$ technique was effectively used to estimate sedimentation rate in the Pungesti Reservoir and to provide chronological measures of soil conservation practises. Gamma spectroscopy, associated with the Canberra MCA S100 system equipped with a $\mathrm{Ge}(\mathrm{Li})$ detector, was used to determine ${ }^{137} \mathrm{Cs}$ concentrations in sediments. Data processing was performed using Microsoft Office 2010 and particular attention was given to 'ground truth' cartographic information.

\section{Results and discussion}

\subsection{Land degradation}

Land degradation has been recognized as the major cause of environmental degradation worldwide and, in particular, in the Moldavian Plateau of eastern Romania. A map of soil losses by erosion from agricultural land, with five erosion classes, was created by using the USLE as adapted to Romanian conditions (Figure $5)$.

The classes between $7-25 \mathrm{tha}^{-1} \mathrm{y}^{-1}$ contribute an estimated $62 \%$ of the total, and $19 \%$ of soil loss is assigned to class $>25 \mathrm{tha}^{-1} \mathrm{y}^{-1}$. The mean estimated soil loss by water erosion (rill and inter-rill) on agricultural land is $19.0 \mathrm{t} \mathrm{ha}^{-1} \mathrm{y}^{-1}$. Adjusting 
for the sediment contribution from woodlands, the mean specific sediment yield (SSY) significantly decreases to $12.8 \mathrm{tha}^{-1} \mathrm{y}^{-1}$.

The most numerous gullies from Upper Racova Catchment are discontinuous and occur on slopes and along valley-bottoms. In study area the present total gully length is $103.7 \mathrm{~km}$ and thus gully density is $1.34 \mathrm{~km} \mathrm{~km}^{-2}$. The high value, exceeding $1.0 \mathrm{~km} \mathrm{~km}^{-2}$, typifies a northern gully strip located in the upper catchment of the valley network (Figure 6). By combining information from LiDAR images, ortophotoplans delivered in 2009 and field observations, it was estimated that the area covered by gullies is small ( $2.4 \%$ of the total, $184 \mathrm{ha})$. However, they play important roles both in the triggering or reactivation of landslides and sediment detachment and transport.

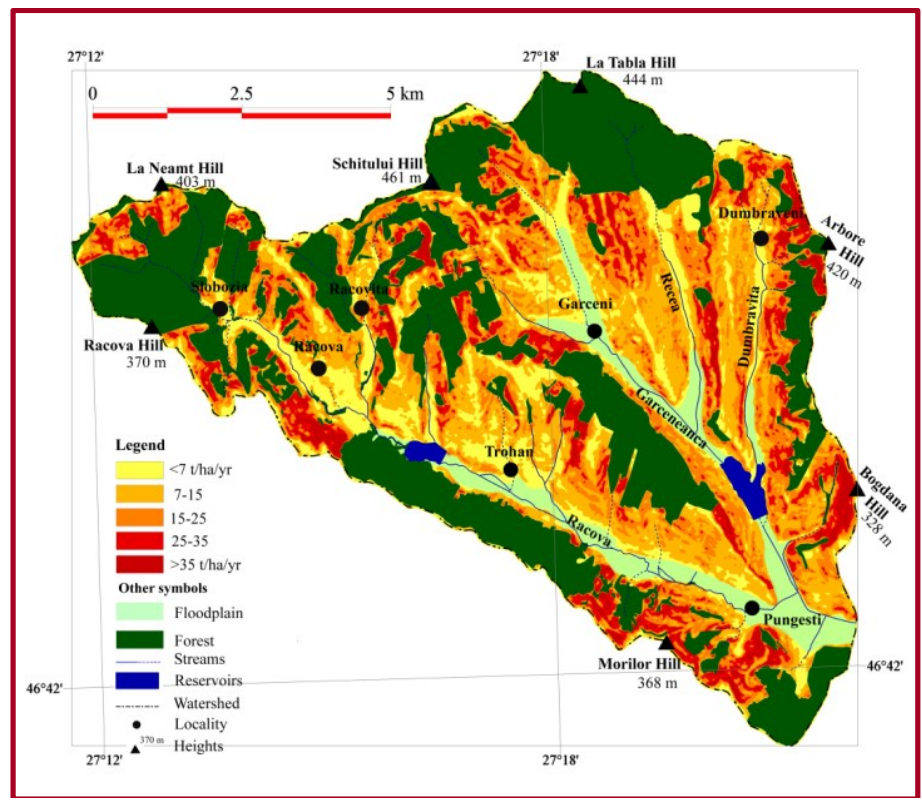

Fig. 5. Map of soil losses from agricultural land in Upper Racova Catchment.

By far, landslides represent the most representative geomorphic process contributing to land degradation within Upper Racova Catchment. The landslide inventory and map (Figure 7) shows that landslides are highly variable in size, age and form, and total $58 \%$ (4,505 ha) of the catchment area. Most of the landslides are shallow and dormant (stable). The active ones form only $\sim 2 \%$ of the total landslide area (TLA), which is a typical value for the Central Moldavian Plateau. 
However, after the rainier 1986-1973 period, active landslides occupied $21.4 \%$ of the TLA (Ionita et al., 2014).

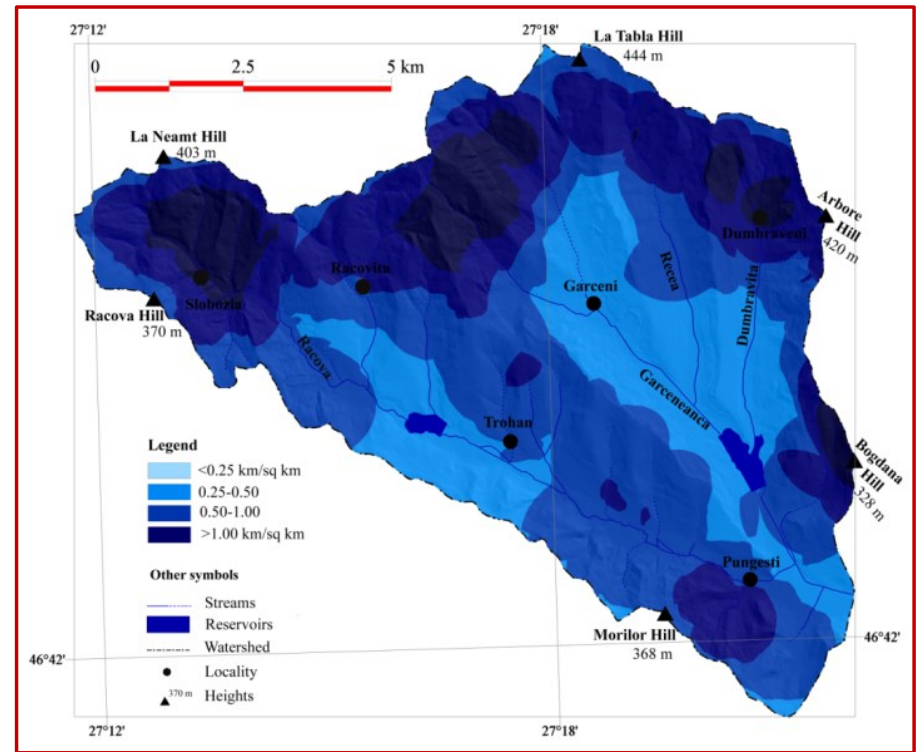

Fig. 6. Map of gully density in Upper Racova Catchment.

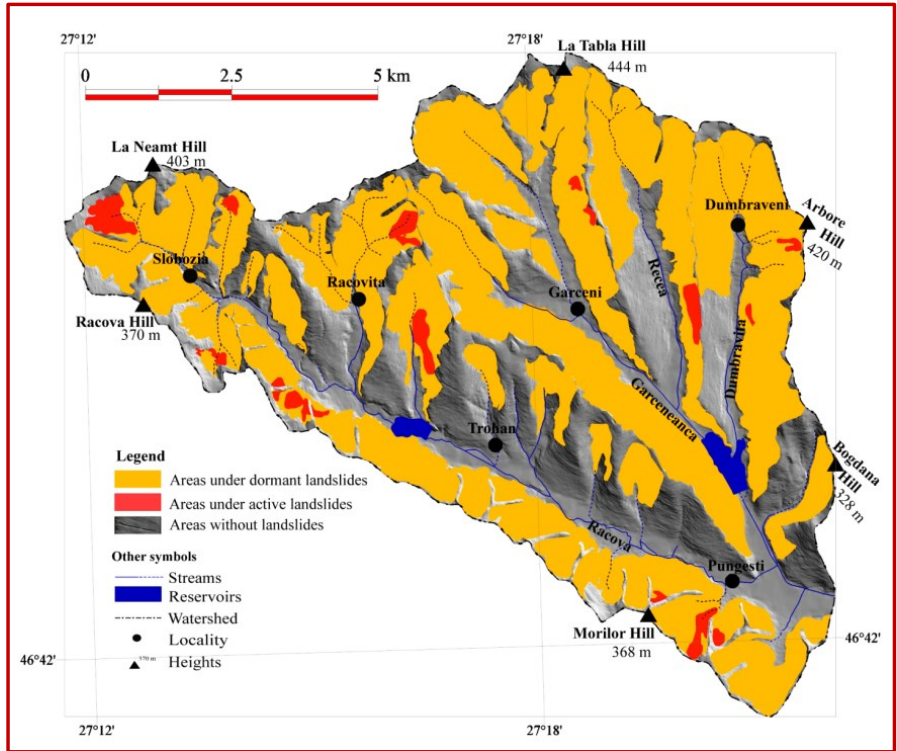

Fig. 7. Landslide distribution in Upper Racova Catchment. 
Sedimentation represents another geomorphic process with special implications on the local environment and targets floodplain aggradation and reservoir siltation, especially. In the context of more precipitation over 1968March 1973, two dams were built in the study area, namely: Pungesti on Garceneanca floodplain and Trohan on Racova floodplain. They became operational in 1976 and 1982, respectively (Figure 8).

Sediment deposition is uneven and adopts a deltaic shape as suggested by Figures $9 \& 10$. The initial area of Puscasi Reservoir at normal retention level (NRL) of 46.2 ha has decreased by $17.5 \%$ to its current area of 38.1 ha.

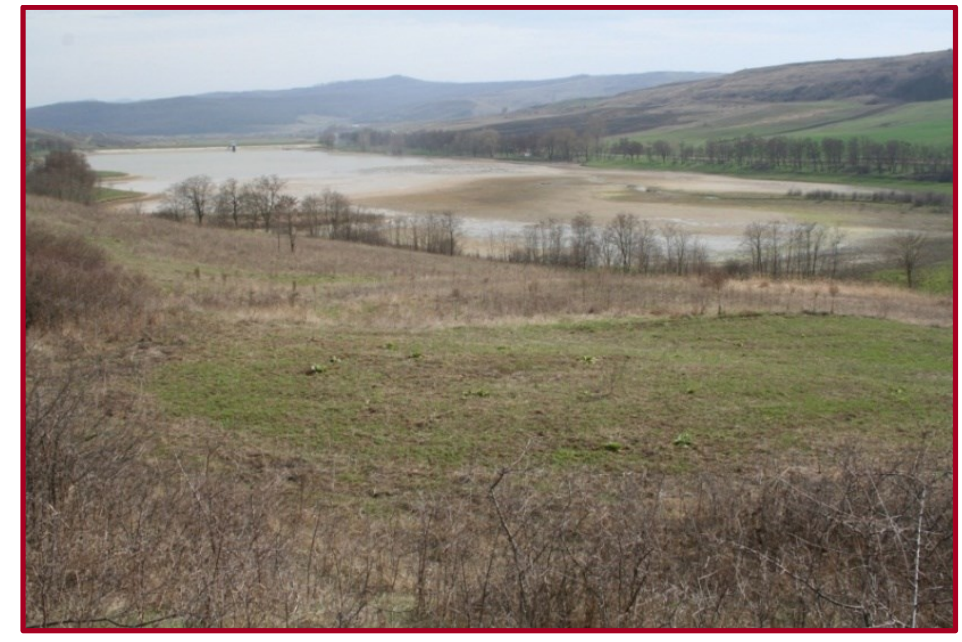

Fig. 8. Pungești Reservoir on Garceneanca floodplain (05 April 2018).

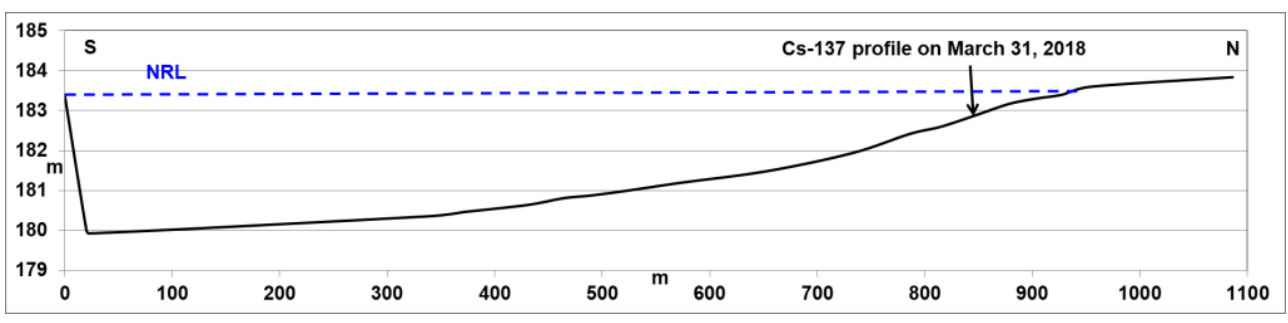

Fig. 9. Longitudinal profile on the floor of Pungesti Reservoir on May 11, 2018. 


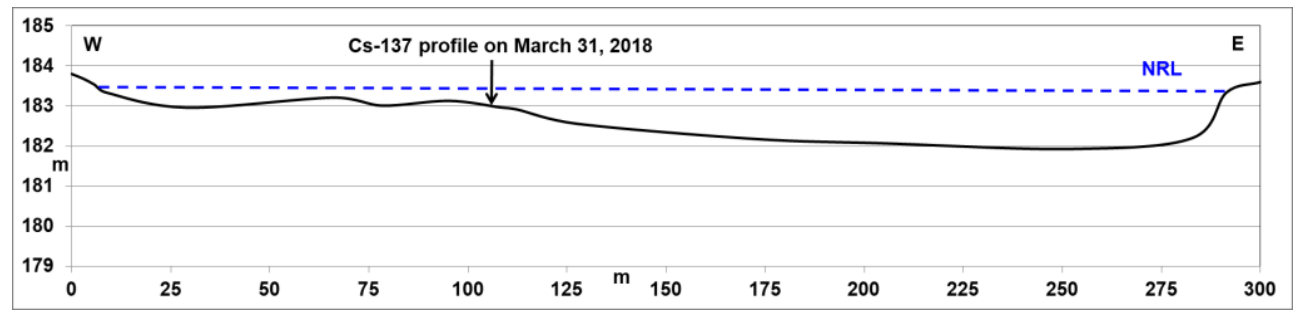

Fig. 10. Cross-section through the Pungesti Reservoir, $830 \mathrm{~m}$ upstream of dam.

During field measurements carried out in spring 2018, when Pungesti Reservoir was temporarily almost emptied, three soil profiles were dug and sampled at $5 \mathrm{~cm}$ depth interval to investigate ${ }^{137} \mathrm{Cs}$ depth distribution. Figure 11 illustrates that the peak value of Cs-137 from one profile occurs at $60-65 \mathrm{~cm}$ and, therefore, the mean sedimentation rate over 32 years (1986-2018) is $2 \mathrm{~cm} \mathrm{yr}^{-1}$.

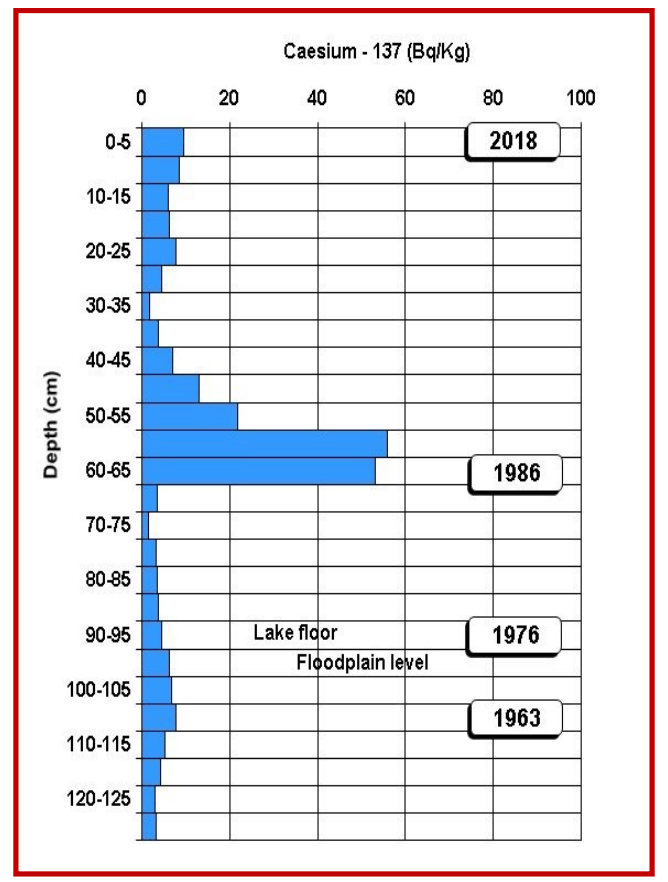

Fig. 11. Depth profile of Cs-137 in the Pungești Reservoir on 31 March 2018 
The Cs-137 values decrease between $65-30 \mathrm{~cm}$ depth and a revival of the Cs137 content is noticeable in the top $30 \mathrm{~cm}$. This distribution resulted from implementing the provisions of Act No. 18/1991, since the contour farming has been replaced by the traditional 'up-and-down slope' farming under small plots.

Overall, the Cs-137 depth profile is very similar to that reported by Ionita et al. (2000) located in the same spot, but the mean sedimentation rate over 12-years (1986-1998) was surprisingly higher, $3.2 \mathrm{~cm} \mathrm{yr}^{-1}$. The decreasing siltation rate in the Pungesti Reservoir (estimated at ca. $1 \mathrm{~cm} \mathrm{yr}^{-1}$ since 1998) depends on increasing the share of both abandoned land and the high degree of weeding.

\subsection{Land management}

By 1960, the traditional agricultural system on the hills of the Moldavian Plateau consisted of 'up-and-down-slope' farming, with $\sim 90 \%$ of agricultural land divided into small $(<1 \mathrm{ha})$ plots. After 1960, these areas were turned into cooperative farms. The remaining larger plots $(\sim 10 \%$ of the area) were transferred from farmers to State farms. After several decades of quiescence, many new, innovative research studies on soil erosion control were initiated (Motoc et al., 1975 \& 1992; Nistor \& Ionita, 2002; Ionita et al., 2006). The first priority consisted of implementing one or more conservation practises starting with contour ploughing.

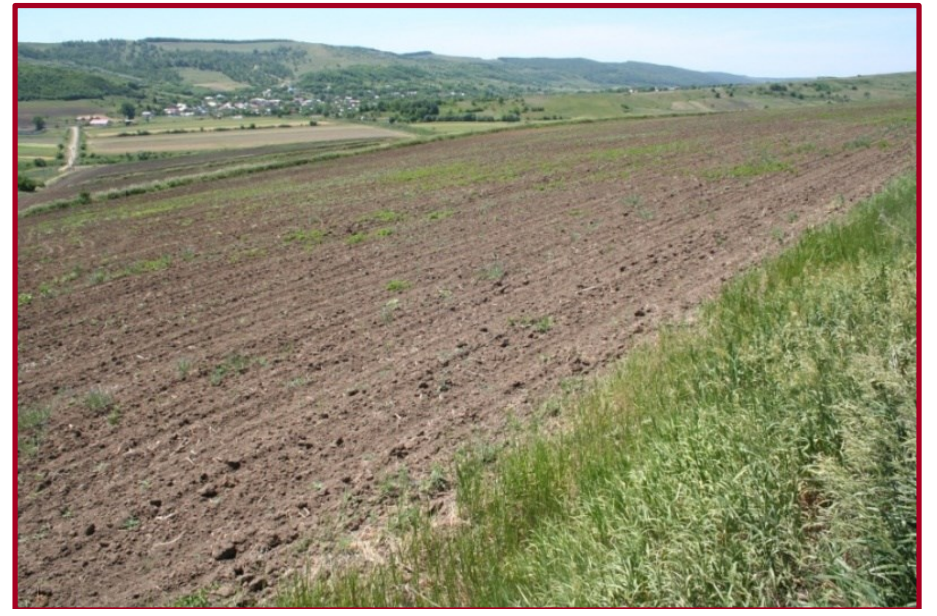

Fig. 12. Remnants of bench terraces on the left side of Racova Valley at Pungești (31 May 2018). 
Land changes within Racova Catchment mirrored the general changes within the entire Moldavian Plateau. During the 20 year period (1970-1989) much soil conservation work was accomplished, especially by IEELIF Vaslui (Enterprise for Performing and Exploiting the Land Improvement Works), namely:

- The design and construction of dams and reservoirs, as already mentioned.

- Design and construction of check-dams to control gully erosion in the tributaries of the River Racova.

- Design and implementing soil conservation practises on slopes in large farms, namely: strip-cropping, buffer strip cropping and bench terraces (Figure 12).

- Design and construction of the agricultural road network.

- Design and building drainage systems.

- Filling small gullies, land reshaping using topsoil and improving pastures.

- Large-scale afforestation.

After implementing provisions of Act No. 18/1991 (of the Agricultural Real Estate), the former short-lived contour farming system almost disappeared and the 'up-and-down slope' farming under small plots is prevalent again (Figure 13).

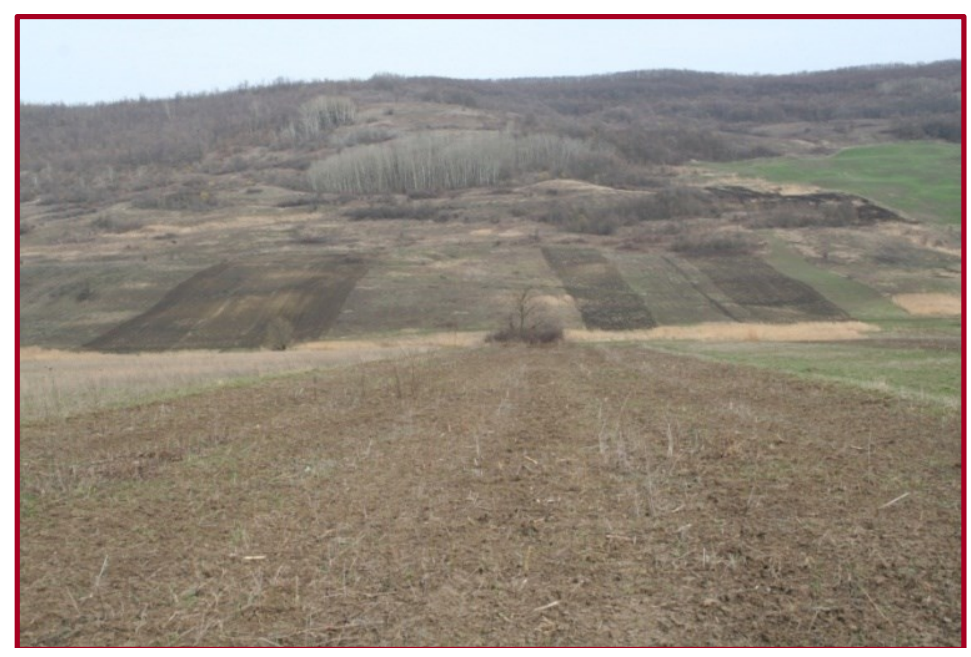

Fig. 13. The impact of implementing provisions of Act No. 18/1991 in Dumbrăvița Valley (05 April 2018).

The case of the 869 ha Dumbrăvița sub-catchment, a left tributary of Garceneanca Catchment, illustrates this surprising evolution. Thus, a combination 
of contour strip cropping system and bench terraces were implemented on 122 ha of arable land on the right side (east facing cuesta back-slope) of Dumbrăvița Valley. Here, on a field with average slope of $13.3 \%$, fifteen bench terraces, spaced at 55-90 m intervals, were combined with sixteen strip crops, each covering 1.115.4 ha (7.6 ha in average) as shown in Figure 14.

Currently, the same field comprises 139 small individual plots of 0.88 ha in average size, most of them orientated up-and-down slope (Figure 15). Similar examples can be readily identified throughout the study area, since there have been identified 2,402 small plots on slopes and their average size is 0.77 ha. Under these circumstances it is difficult to design and implement the best management practises to control soil erosion and improve the quality of local environment.

\section{Conclusions}

The 7,766 ha Upper Racova Catchment on the Central Moldavian Plateau is highly susceptible to land degradation, due to both natural conditions and human impacts. The local relief is typically hilly and half of the catchment area $(3,946 \mathrm{ha})$ range from $200-300 \mathrm{~m}$ a.s.l.

Most of the study area is comprised of slopes $(6,242$ ha, $80.4 \%$ of Upper Racova Catchment) and they usually represent cuesta fronts and/or cuesta backslopes.

The mean value of soil losses by water erosion on agricultural land is estimated to be $19.0 \mathrm{t} \mathrm{ha}^{-1} \mathrm{y}^{-1}$. By adding the woodland contribution, this value significantly decreases to $12.8 \mathrm{tha}^{-1} \mathrm{y}^{-1}$ but remains problematically high.

Area under gullies is relatively small (184 ha and $2.4 \%$ of the total) but gullying plays important roles, both in the triggering or reactivation of landslides and sediment detachment and transport.

The most characteristic feature of the study area is the large proportion of land (58\%) covered by landslides. Most of them are shallow and dormant (stable), and the active ones form only $\sim 2 \%$ of the total landslide area, which is a typical value for the Central Moldavian Plateau.

The mean sedimentation rate over 32 years (1986-2018) in the Pungești Reservoir is $2 \mathrm{~cm} \mathrm{yr}^{-1}$. The decreasing siltation rate since 1998 (estimated at ca. 1

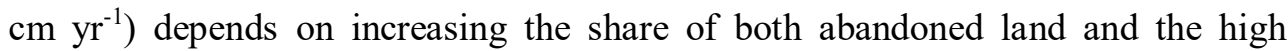
degree of weeding.

Proper conservation measures were designed and applied over a 20 -year timespan from 1970-1990. After implementing the provisions of Act No. 18/1991, the contour farming system collapsed and returned to the traditional 'up-and-down slope' farming system on very small plots. 
112 Samoilă Claudia, Ioniță Ion, Niacșu Lilian, Grigoraș Georgel, Blebea-Apostu Ana Maria

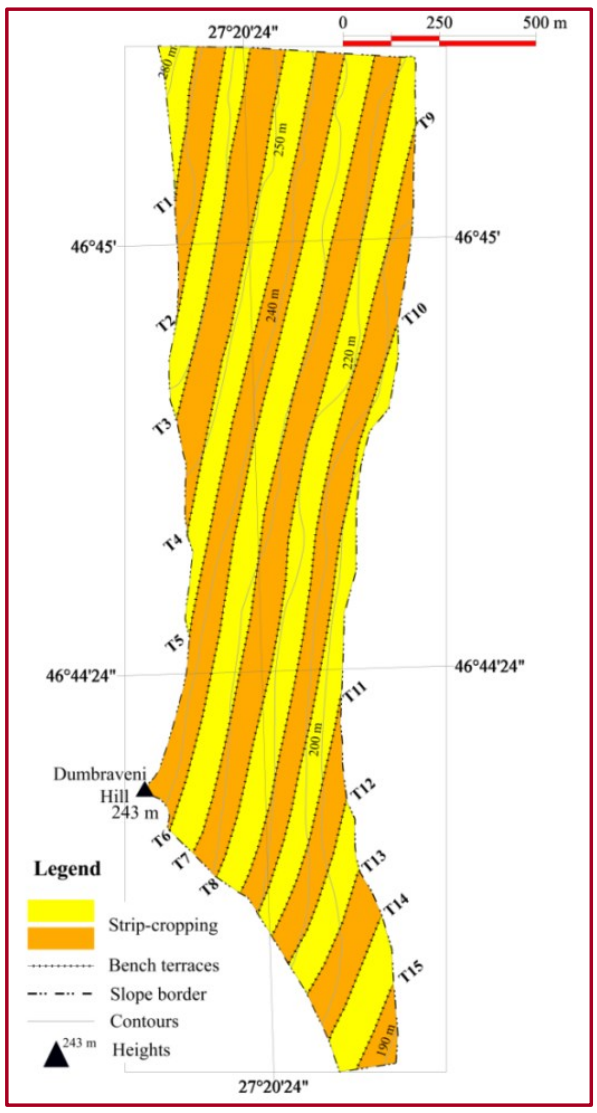

Fig. 14. Former combination of stripcropping and bench terraces in Dumbrăvița Valley.

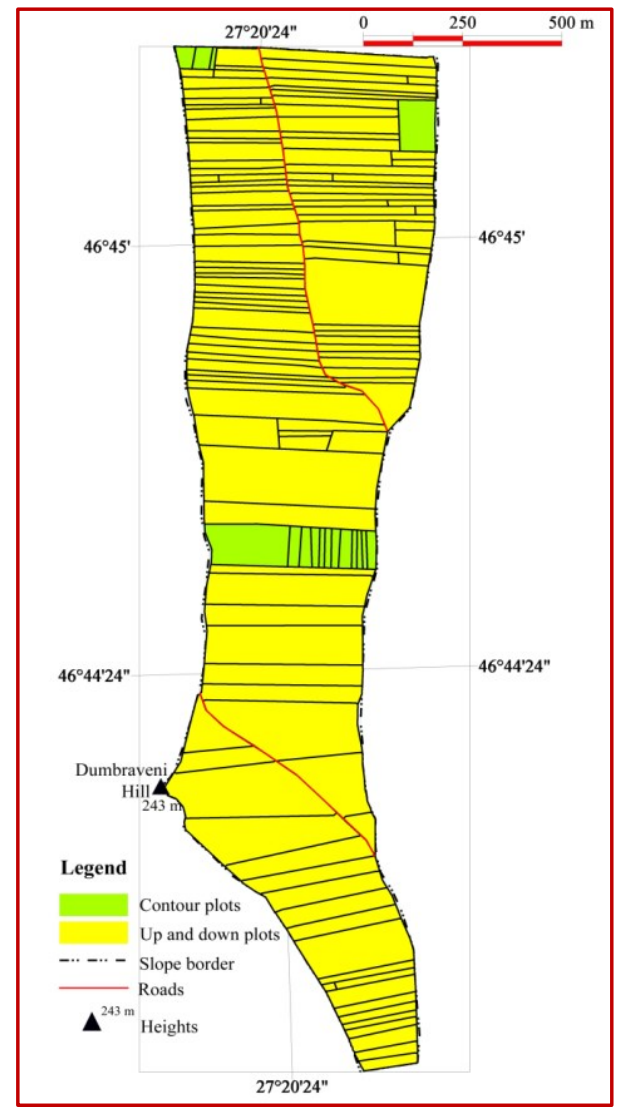

Fig. 15. Outline of present-day 'up-anddown' hill small plots in Dumbrăvița Valley.

\section{References}

Băcăuanu, V., Barbu, N., Pantazică, Maria, Ungureanu, Al., Chiriac, D., 1980, Podișul Moldovei. Natură, om, societate, Editura Științifică și Enciclopedică, București, Romania, $347 \mathrm{p}$.

Ionesi, L., 1994, Geologia unităţilor de platformă şi a Orogenului Nord - Dobrogean, Editura Tehnică, Bucureşti.

Ioniţă, I., 1998, Studiul geomorfologic al degradărilor de teren din bazinul mijlociu al Bârladului, Teză de doctorat, Universitatea „Alexandru Ioan Cuza”, Iași.

Ioniță, I., 2000, Relieful de cueste din Podişul Moldovei, Editura Corson, Iași.

Ioniţă, I., Mărgineanu, R.M., Hurjui, C., 2000, Assessment of the reservoir sedimentation rates from 137-Cs measurements in the Moldavian Plateau, In 
"Assessment of Soil Erosion and Sedimentation Through The Use of The 137-Cs and Related Techniques", Queralt, I., Zapata, F. and Garcia Agudo (eds.), Acta Geologica Hispanica, 35 (3-4), 357-367 p.

Ioniță, I., Chelaru, Petronela, Niacșu, L., Butelcă, D., Andrei, A., 2014, Landslide distribution and their recent development within the Central Moldavian Plateau of Romania, Carpathian Journal of Earth and Environmental Sciences, 9 (3), 241-252 p.

Jeanrenaud, P., 1961, Contribuții la geologia Podișului Central Moldovenesc, Analele Științifice ale Universității "Alexandru Ioan Cuza" Iași, s II, t. VII.

Jeanrenaud, P., 1971, Harta geologică a Moldovei centrale dintre Siret și Prut, Analele Ştiinţifice ale Universităţii „Alexandru Ioan Cuza”, Iași, s. II, t. XVII, 65-78 p.

Motoc, M., 1970, Estimation de l'influence des facteurs d'érosion, In "International Water Erosion Symposium - Proceedings II", Prague.

Moțoc, M., 1983, Ritmul mediu de degradare erozională a solului în R.S. România, Buletin Informativ ASAS, 2, București, România, 67-73 p.

Moțoc, M., Munteanu, S., Băloiu, V., Stănescu, P., Mihai, Gh., 1975, Eroziunea solului şi metodele de combatere, Editura Ceres, București.

Moțoc, M., Ioniță, I., Nistor, D., Vatau, A., 1992, Soil Erosion Control in Romania. State of the Art, In "Soil Erosion Prevention and Remediation Workshop" U.S. Central and Eastern European Agro-Environmental Program, Budapest, 111-133 p.

Nistor, D., Ioniță, I., 2002, Development of soil erosion control in Romania, In: Rubio, J.L., Morgan, R.P.C., Asins, S, et al. (eds), Proceedings of the Third International Congress Man and Soil at the Third Millennium. Valencia, Spain, 28 March-1 April. Logrono: Geoforma Ediciones, 299-309 p.

Samoilă, Claudia, Ioniță, I., 2017, Racova catchment. Geomorphological peculiarities, Lucrările Seminarului Geografic "D. Cantemir", 44, Editura Universității „Alexandru Ioan Cuza”, Iași.

Ungureanu, Al., 1993, Geografia podişurilor și câmpiilor României, Editura Universității "Al. I. Cuza" Iasi, Romania.

Wischmeier, W.H., Smith, D.D., 1960, A Universal Soil-Loss Equation to guide conservation farm planning, Trans. Int. Congr. Soil Sci., 7th, 418-425 p.

Wischmeier, W.H., Smith, D.D., 1978, Predicting Rainfall Erosion Losses, A Guide to Conservation Planning, USDA Agriculture Handbook No. 537. USDA: Washington DC, USA. 